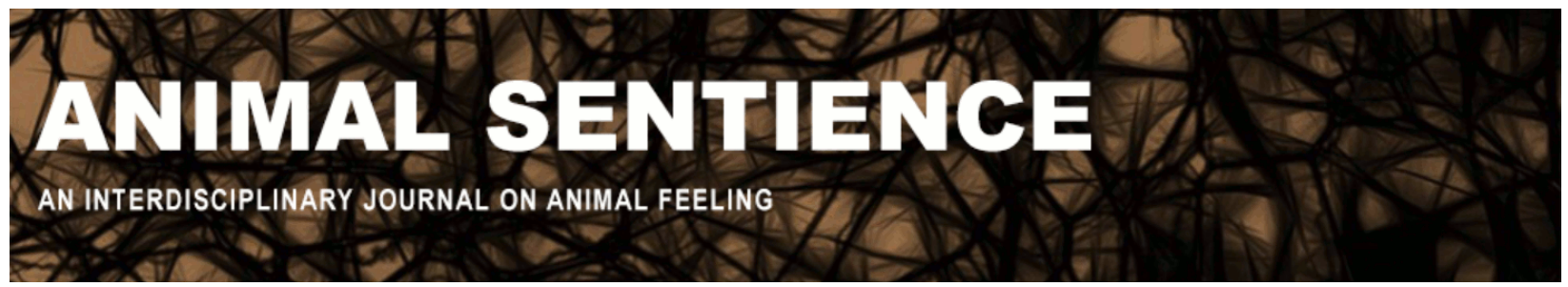

Lachance, Martine (2016) Breaking the silence: The veterinarian's duty to report. Animal Sentience 6(1)

DOI: $10.51291 / 2377-7478.1018$

Date of submission: 2015-06-27

Date of acceptance: 2015-12-11

(c)

This article has appeared in the journal Animal

Sentience, a peer-reviewed journal on animal

cognition and feeling. It has been made open access,

free for all, by WellBeing International and deposited

in the WBI Studies Repository. For more information,

please contact

wbisr-info@wellbeingintl.org.

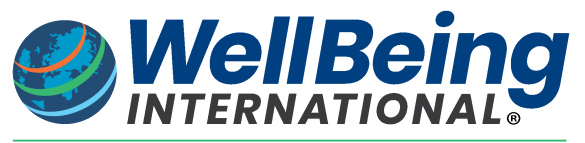

SOLUTIONS FOR PEOPLE, ANIMALS AND ENVIRONMENT 
Call for Commentary: Animal Sentience publishes Open Peer Commentary on all accepted target articles. Target articles are peer-reviewed. Commentaries are editorially reviewed. There are submitted commentaries as well as invited commentaries. Commentaries appear as soon as they have been revised and accepted. Target article authors may respond to their commentaries individually or in a joint response to multiple commentaries.

Instructions: $\underline{h t t p: / / a n i m a l s t u d i e s r e p o s i t o r v . o r g / a n i m s e n t / g u i d e l i n e s . h t m l ~}$

\title{
Breaking the silence: The veterinarian's duty to report
}

\author{
Martine Lachance \\ Juridical Sciences \\ Université de Québec à Montreal, Canada
}

\begin{abstract}
Animals, like children and disabled elders, are not only the subjects of abuse, but they are unable to report and protect themselves from it. Veterinarians, like human physicians, are often the ones to become aware of the abuse and the only ones in a position to report it when their human clients are unwilling to do so. This creates a conflict between professional confidentiality to the client and the duty to protect the victim and facilitate prosecution when the law has been broken. I accordingly recommend that veterinarian associations make reporting of abuse mandatory.
\end{abstract}

Keywords: veterinarian, duty to report, confidentiality, animal abuse, mistreatment

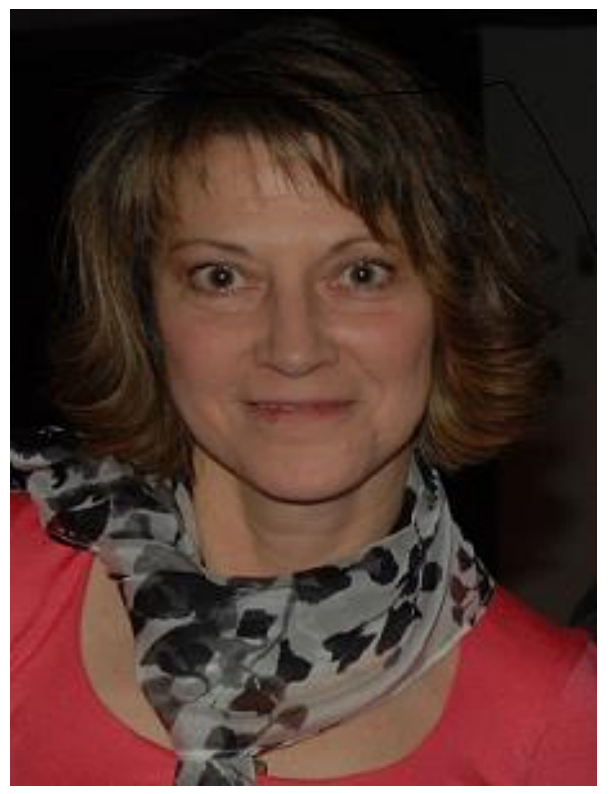

Martine Lachance lachance.martine@uqam.ca is Professor, Department of Juridical Sciences, Université du Québec à Montréal, Montréal, Québec, Canada H2X 2J6. Her research and teaching interests include family law, private international law and animal law. In 2007 she established International Research Group in Animal Law (GRIDA). She has supported the Canadian Veterinary Medical Association in opposing the adoption of Bill S-203. She currently serves on the Animal Well-Being Committee of the Ordre des médecins vétérinaires du Québec. Through GRIDA, she organized and hosted the first international conferences in animal law in Canada: "The Animal Within the Sphere of Human Needs" (2009) and "Does the Law Consider Animal Suffering?" (2011). The $3^{\text {rd }}$ edition of the international conference, "Animal Sentience: From Science to Law" was held in Paris on October 2012. As GRIDA's director, Martine was invited in September 2015 to express her view on Bill 54 proposed by the provincial government. http://grida.uqam.ca/en.html 
Breaking the silence: but what kind of silence needs to be broken? This is the first question we must answer, because silence breeds indifference whenever it is impossible to speak, or one refuses to speak, or even when one is forbidden to speak.

The first type of silence is the silence of animals, who are voiceless because they can neither verbalize their suffering in a language understandable to human beings nor defend their interests in interactions with human beings. The second silence is that of human beings who, ever asserting exceptional status in their relationships with the animal world, choose not to speak about animal suffering. The third is the silence imposed on human beings deprived, for various reasons, of their freedom to speak.

Freedom of speech is denied not only in dictatorships, but also in democracies wherever the law prohibits disclosure to a third party of information that has been shared in a relationship based on trust. In such cases, silence has a social function: protecting the bond of trust, which is essential to protecting the integrity of the relationship between two persons. Hence there, silence may be legitimate and desirable.

The right to remain silent ${ }^{1}$ under police interrogation or in a court of law, for example, protects individuals from self-incrimination. This reinforces the bond of trust between citizens and the justice system, despite the power asymmetry between the individual and the State. Under certain circumstances, to protect conjugal trust, the law cannot be used to force spouses to testify against one another. The law also prevents professionals from disclosing privileged information acquired during the exercise of their functions. ${ }^{2}$ The betrayal of professional/client confidence is considered a violation of fundamental human rights. ${ }^{3}$

Veterinarians represent the only professional body of interest to our research because they work in close proximity with animals. In some respects, the rule of professional confidentiality imposed on veterinarians (as well as human physicians) "can be justified for purely historical reasons, as established by long standing practice, going as far back as the Hippocratic Oath" (Morissette and Shuman, 1984, p. 511). The oath of allegiance taken by veterinarians when they are sworn in as members of their profession becomes a guarantee of confidentiality in professional practice (Labrie vs Roy, 2003). Veterinarians pledge to protect the health and welfare of animals and to respect the dignity and honor of the veterinary profession. However, this undertaking (or oath), which the Court of Human Rights of Québec has deemed to be "mostly related, if not identical, to the concept of

1 This is a fundamental right under the Canadian legal system, which is protected under the Constitution (Section 7 of the Canadian Charter of Rights and Freedoms).

2 Québec, see Charte des droits et libertés de la personne, article 9; Code des professions, L.R.Q., vs C26, art. 60.4

3 In Quebec, the right to professional confidentiality has become a fundamental right in section 9 of the Charter of Rights and Freedoms. 
professional secrecy" (Bissonnette vs Mercure, 1996, p. 33), requires that veterinarians remain silent about what they have discussed with their clients. ${ }^{4}$

Whatever their area of practise, whether in a veterinary hospital, a private clinic, the pharmaceutical industry, the agri-food sector, or environmental and wildlife services, the main duty of veterinarians is to protect animal health. In their clinical interventions, veterinarians must take into account both the physical welfare and the behaviour of animals.

The two distinct values that veterinary associations seek to uphold are (1) animal welfare and (2) professional secrecy. Their legal protection has depended on the rules of their local legal systems. The rules for both of these values are well founded. For (1), the objective is to minimise needless animal suffering (Coulon, $2013)^{5}$ and for (2) it is to provide full legal protection to the client-practitioner relationship (Morissette and Shuman, 1984). ${ }^{6}$

In animal breeding and biomedical research, to name only two important industrial and economic subdomains, animal suffering is systemic:

In times when funding for "animal welfare" has become as abundant as academic conferences on the subject, animal suffering ... has reached unparalleled heights....Such ... suffering may not always be visible, but it is closely linked to the merciless nature of the system. (Camos et al., 2009)

We cannot address this institutionalized form of animal suffering in this paper. Instead, we will examine suffering that is inflicted on animals individually, and needlessly, by individual human beings. This kind of suffering can be seen as a basic extension of classical human social ills; in the special case of animals, its most fundamental cause is the unconstrained domination of humans over animals. As long as this domination is not faced squarely and challenged, it will continue to be denied or trivialized.

As Gagnon (2011) notes, "The life expectancy of a household pet in a home where violence is present is rarely more than two years: the pet is usually killed by negligence or harm, or it flees the inhospitable environment." Animals subject to abuse, if their aggressor does not kill them outright, usually end up in a veterinary clinic to be treated for their injuries. Through their medical functions, veterinarians hence usually represent the first line of intervention beyond the locus of the violence. They are usually in a position to detect animal abuse. Because professional veterinarians are at the forefront of treatment, their awareness of their social responsibility and their understandable revulsion in the face of gratuitous animal suffering becomes a tremendous burden.

4 Code of Ethics of Veterinary Surgeons, RLRQ, vs M-8, art. 23. See also the Q.S.B. Invs (Santé Animale Breton) vs Ordre des Pharmaciens du Québec, 2003 CanLII 48383 QCCS ruling in which the judge stated that "veterinary doctors are subject to the duty of professional secrecy like any other professional."

5 "This is the very premise of protective rules for animal rights" (p. 27).

6 "In most contemporary doctrine, professional secrecy lies in the bond of trust" (p. 512). 
The following tragic example, experienced personally by American professor Bernard E. Rollin (2008), clearly and unambiguously underlines the ethical and legal dilemma that professional veterinarians face when dealing with abuse:

I experienced a dramatic example relevant to this claim when a client brought a comatose dog into our veterinary hospital, and boasted that the inception of the coma took place when he struck the animal with a frying pan when the dog was barking incessantly. After the dog died, the pathologist performing the necropsy discussed the case with the veterinary students. One of the students worked for the local Humane Society, and asked the pathologist for the client's name so that he could be investigated for cruelty. When the investigation took place, the angry client protested to the school. Numerous clinicians expressed anger to the student and even threatened his future. They affirmed repeatedly that the only ethical issue inherent in this case was the violation of confidentiality. Clearly that is incorrect: there are issues of animal welfare, criminal behavior, the student's duty as a Humane Society employee while a veterinary student, the clinicians' threats etc.

This example already raises the following questions, which until now seem to have received very little attention from the North American veterinary community ${ }^{7}$ : Is a practitioner morally justified to report suspected cases of abuse to the appropriate authorities? If so, is the professional legally authorized to report the case even when bound by the rule of professional secrecy?

\section{Are Veterinarians Morally Justified In Reporting Animal Abuse to the Appropriate Authorities?}

Although there is no scientific basis for the distinction, people tend to segregate sentient organisms into two distinct categories insofar as consciousness is concerned: human and animal. We will accordingly treat the moral and legal considerations for each category separately.

In light of the empirical evidence of sentience in a growing number of species (Broom, 2014; Dawkins, 2012; Duncan, 2006; Proctor et al., 2014; Safina, 2015), recent moral and legal theories (Armstrong, 2003; D'Silva \& Turner, 2012; Garrett, 2012; Regan, 2003; Rollin, 2015; Wise, 2014) have lead researchers to find the existing tolerance of violence against animals increasingly untenable. In addition, there is evidence that gratuitous violence toward animals is associated with violence toward human beings (Felthous et al., 1987; Gillone, 2014; Lockwood \&

7 This was the position confirmed by Dr. Lorelei Wakefield, an American veterinarian during an online debate organized by Sentience Mosaic in 2013 dealing with the subject of animal behavior, cognition and emotions: http://www.animalmosaivsorg/sentience/Debates/pastdebates $/$ default.aspx?page=0\&debate=tcm:46-35604. 
Ascione, 1998; Tiplady, 2013). Animal sentience and the correlation of violence against animals with violence against humans are treated in the next two sections.

Animal sentience. At the time of writing this article, several legal systems have recognized the sentient nature of animals. For example, the Law Commission of the National Assembly of France recently recognized that animals are "living beings endowed with sentience ${ }^{8}$." At the same time, the Minister of Agriculture, Fisheries and Food in Quebec has introduced draft legislation to modify the Civil Code of Quebec so as to accord sentient status to companion animals as well as farm animals ${ }^{9}$. What is animal sentience? It is the capacity to feel, rather than just to react to stimulation mechanically, the way robots or organisms without nervous systems do? Chapouthier and Bovet (2013, p. 16), for their part, differentiate three levels of animal sensibility:

The basic mechanism in the pain process is known as "nociception," which triggers an automatic response (reflex), whereby the [animal] is able to react to any threatening agents....When nociception is reinforced by emotional responses we speak of "pain." When nociception and pain are combined with cognitive awareness, we may then speak of "suffering."

The growing recognition and understanding of the biological and psychological reality underlying sentience in more and more kinds of animals is transforming our attitudes concerning the ethical acceptability and the social tolerability of people making them suffer. Advances in ecology and ethology have increased our social awareness of animals and their plight at human hands. Aggression against a defenceless animal is one of the most significant and flagrant manifestations of human violence. Brutality toward helpless, vulnerable beings inescapably calls to mind similar forms of domination and abuse directed at the weaker members of our own species. Our convergent perception of the plight of victims, whether human or animal, is hence further reinforced by the scientific evidence of the capacity to suffer that is shared by all sentient beings.

Professional clinicians are faced with the suffering of sentient victims who cannot understand or explain how or why they are suffering. Under these conditions, compassion, either as a direct reaction or as a result of empathy with the suffering, becomes a legitimate basis for moral intervention by the veterinarian.

Correlation between acts of violence committed against animals and human beings. There is no longer any doubt about the links between the disposition to commit violence against animals and the disposition to commit violence against

8 http://www.lemonde.fr/planete/article/2015/01/28/les-animaux-sont-desormaisofficiellement-doues-de-sensibilite 4565410 3244.html.

9 http://www.assnat.qvsca/fr/travaux-parlementaires/projets-loi/projet-loi-54-41-1.html. 
other humans (Felthous et al., 1987; Gillone, 2014; Lockwood \& Ascione, 1998; Tiplady, 2013). This correlation, which extends from injury to killing in both cases, is far from new. A long list of thinkers has already argued that "cruelty against the one is susceptible to trigger cruelty against the other: from Pythagoras to Schweitzer, by way of Thomas Aquinas, Locke, Kant, Schopenhauer and many others" (Linzey, 2012).

The anthropologist Margaret Mead was one of the first social scientists to argue that impulsive acts of aggression against animals at a young age may contribute to violent behavior in adulthood (Mead, 1964). Research on the subject has since greatly increased. The following results are from studies conducted on convicted criminals and offenders:

- A retrospective study conducted in 1986 by Tringle et al. (Linzey, 2012) on prison inmates found that $48 \%$ of the subjects convicted of rape had a prior history of cruelty against animals.

- In a sample of 28 perpetrators of sexual homicide, $36 \%$ had committed acts of cruelty against animals during childhood and an additional 10\% during adolescence (Ressler et al. 1988).

- A 1997 study by the Massachusetts Society for the Prevention of Cruelty to Animals and Northeastern University (Frazier, 1998) found that 70\% of those who abused the animals had committed at least one other criminal offence and that almost $40 \%$ of them had committed violent crimes against human beings.

Both academics and clinicians have turned their attention to the joint occurrence of family violence and animal abuse ${ }^{10}$ :

- In a 1983 landmark study in the United States, Deviney et al. (1998) examined the behavior of 53 families in New Jersey who met the legal criteria of child abuse and neglect. Sixty percent of them had also been convicted of violence or neglect against companion animals. Among $88 \%$ of the families in which the children had been victims of violence, ${ }^{11}$ the pets had also been victims of abuse.

- In a Canadian study, McIntosh (2004) found that 56\% of women who had companion animals and who had sought refuge in shelters for battered women reported that the perpetrators of the violence had also threatened or seriously

10 In its official journal, the Quebec Order of Veterinarians published a special issue on the theme of animals trapped in a spiral of family violence: Le Vétérinarius, Vol. 27, no. 1, February 2011.

11 Children who are the victims of violence themselves become perpetrators of violence. This was the case of Mary Bell, an "11-year-old girl who killed two little boys of 3 and 4. She was especially violent as she strangled cats and birds. She had been abused by her mother, who tried to kill her 4 times and had forced her into prostitution in a sadomasochist context." The case was reported in One Voice: http://www.one-voice.fr/jecoute-ma-conscience/aux-editions-one-voice-les-animauxet-les-humains-le-lien/. 
harmed the companion animal. Sixty-five percent of these women believed that their children were aware of the violence committed against the companion animals and were seriously affected by the abuse.

Among researchers, there is agreement that violence usually begins with violence against animals, which in turn makes the perpetrators increasingly insensitive towards the suffering of others. This is why many professional law associations have criminalized cruelty towards animals. Criminal law prohibiting cruelty towards animals is intended in part to protect people from violence (Francione, 1994).

When confronted with animal injuries, the veterinarian is the only professional who is qualified to make a diagnosis of abuse. This takes place after the case history ${ }^{12}$ and clinical examination of the animal. When either the health or wellbeing of an animal is judged to be in danger, the veterinarian has a double responsibility, to protect the animal victim and to ensure the ethical treatment of animals as well as to comply with the law. The veterinarian needs to resolve the ethical dilemma and ambiguity that has been dividing the profession: reporting an abusive situation ${ }^{13}$ may be a betrayal of professional secrecy, but remaining silent is a betrayal of the patient, as well as of one's own conscience. Now let us examine whether it is possible to breach the code of professional secrecy, by which the veterinarian is bound, by distancing oneself from what was initially important for professional confidentiality.

\section{Is the Veterinarian Authorized to Report Animal Abuse to the Competent Authorities?}

The right to professional secrecy is a fundamental right (Poulin vs Prat, 1994); it gives priority to the prerogatives of the individual against those of the group. As underlined by Marie-Luce Pavia (1994), "in its deepest and original sense, a right may be called fundamental when it is an essential component of - that is when it establishes - the identity of a person in a democratic society." From a legal perspective, a fundamental right derives from its higher ranking in the hierarchy of standards. Fundamental rights are protected under the Charter of Human Rights and Freedoms, ${ }^{14}$ and in Quebec they have a quasi-constitutional force (Frenette vs La Métropolitaine, Cie d'assurance-vie, 1992.) In accordance with its fundamental status, professional secrecy shares the same rank with other fundamental rights. Because of its underlying values, it can be opposed to and can prevail over other items of law

12 "Information provided by the owner concerning the case history of the animal's health or the sickness of the animal leading up to the consultation with the veterinarian. The case history was performed immediately prior to the general examination of the animal": Le Gardeur Veterinarian Hospital, Lexicon:

http://www.veterinairelegardeur.com/definitions.aspx?itemid=214\&detailview=true.

13 The animal welfare program of the Canadian Veterinary Medical Association (CVMA) has announced that it is the duty of every veterinarian to denounce any suspicion of abuse, whenever the situation of an abused animal cannot be resolved through education of the client: http://www.veterinairesaucanada.net/programs/reporting-animal-abuse.aspx\#.U2PXV1cW3Yk.

14 Charter of Human Rights and Freedoms, R.S.Q, vs C-12, art. 9. 
(Picard, 1998).15 It is fundamental because of the place it holds in the system of values and not because of the place it holds in the hierarchy of standards (Monnier, 2006).

Like other fundamental rights, the right to professional secrecy is never absolute (Baudouin, 1974). ${ }^{16}$ The purpose of legislation is to establish a balance of fundamental rights in order to avoid potential conflicts and to serve the interests of justice. This search for balance may sometimes take precedence over the fundamental right. Other values and concerns for competing interests sometimes require the disclosure of confidential information. Hence in an extra-judicial context, otherwise known as private disclosure, the person who is the provider of confidential information may grant release from professional secrecy (1) or the release may be granted by specific provisions of the law (Archambault vs Comité de discipline du Barreau du Québec, 1992) ${ }^{17}$ (2).

Waiving the right of confidentiality to protect information. Even if medical information disclosed in the veterinarian context does not necessarily have the same degree of importance as in human health, such information is nonetheless just as rigorously protected by professional secrecy. Like other professionals, veterinarians are required to ensure the confidentiality of any information shared by a client.

The courts have confirmed a constant rule that under the right to privacy,18 individuals may themselves determine the limits on the disclosure of confidential information. The client retains control over the information shared with the professional at all times and may at any time waive ${ }^{19}$ that right with no need for justification. However, in the context that is of interest to us, unless abusers choose to clear their consciences or to clear themselves from the burden of guilt, the chances that they will waive their right to protection under professional secrecy are almost nonexistent. How could it be in the abusers' interest to become their own accusers? Can they be expected to do so in the interest of the abused animal, of the general public, or of justice? As this is merely a rhetorical question, let us now turn our attention to the main argument of this text, which concerns whether veterinarians are authorized to report to the appropriate authorities any suspicion of abuse that they might have with regard to an animal in their care.

15 "Fundamental rights are those rights that, in the opinion of the legislator, are sufficiently essential to take precedence over any other legal claim that might [be] evoked against it" (p. 9).

16 Across Canada, both in common law provinces and in Quebec, professional confidentiality is based on a rule of public order, which is merely relative. The Supreme Court of Canada has recognized that this right, notwithstanding its quasi-constitutional nature in Quebec, continues to be, beyond doubt, a relative right: Frenette vs La Métropolitaine, Cie d'assurance-vie. See also Briand vs Forget, 2007.

17 "A provision is express when it does not require any interpretation and is self-explanatory."

18 In Quebec, the right to privacy enjoys quasi-constitutional protection: Charter of Human Rights and Freedoms, L.R.Q., vs C-12, art. 5.

19 This type of waiver may not be presumed. 
Professional secrecy may be overridden by the operation of law. However fundamental they may be, the rights to privacy and to professional secrecy have their respective limits. For the purpose of public interest or public order, they may be overridden to allow disclosure whenever other imperative values or the concerns for competing interests so require (Société d'énergie Foster Wheeler ltée vs SIGED, 2004). As François Ost reminds us: "Public order, which is first and foremost invoked in defence of legality, is often invoked in a more flexible and effective way as a means of protection that serves the interests of the weakest" (Ost and Gérard, 1990, p. 80) (my translation).

Nathalie Maillard has written that "vulnerability is a fundamental feature of human life," which most often involves beings "that do not have the capacity to protect themselves or their interests and are hence subject to manipulation, exploitation or treatment as mere objects" (Maillard, 2011, p. 172) (Our translation). Well beyond the question of autonomy, the recognition of animal sentience is giving the issue of physical and psychic suffering a new and deeper meaning, identifying a vulnerability that needs to be protected.

This vulnerability is already characteristic of every human being while they are still in infancy and childhood. This is the main reason why many jurisdictions, including France and Quebec, ${ }^{20}$ have enshrined the duty to report in the field of pediatrics. But, to quote the unfortunate words of Kant (1967, pp. 73-74), whereas a child has the ability to go on to become autonomous - through language and instruction - an animal "has already become whatever it will become." Animals are sentient beings that need to be protected against gratuitous suffering and hence veterinarians need to be released from their duty of confidentiality as one of the essential means to achieving this goal. Release from the duty of discretion can be achieved in two different ways: either the report of abuse is a right (authorizing the veterinarian to act), or it is a duty (it binds the practitioner).

Release from professional secrecy authorized by law. In this model, reporting abuse is left to the discretion of the professional. By absolving the professional from this obligation, the legislator outlines the responsibilities the practitioner must fulfill. In dealing with the suffering or the death of an animal who has been the victim of mistreatment, veterinarians could have the choice of handling the situation on their own, without recourse from the justice system and without being obliged to report the situation. Alternatively, they could choose to report the suspected abuse to the authorities if they judge that legal intervention is the only solution. This may leave the professional in a state of uncertainty:

On the one hand, the practitioner is torn between his ethical principles, the individual sources of right and the provisions governing secrecy, which protect his rights as a professional; and on the other hand, collective interventions and the obligations to speak out....

20 Youth Protection Act, L.R.Q., vs P-34.1, s. 39. 
For the practitioner, the distinction between a personal approach based on the right to privacy and a collective approach based on public order is very narrow. Professionals often feel that they are torn between this conflict of rights. (AFIREM, 1994, p. 187)

Voluntarily acting against the interests of a client requires considerable assurance. The practitioners must be convinced that what they are doing is right. The choice between two strategies - one based on counselling the client and the other based on legal intervention - must be based on the professional's own convictions (Massol, 1862). The decision will be influenced by many factors related to biobehavioral science as well as animal health, including the veterinarians' capacity for compassion towards an abused animal, respect for privacy, perception of duty, and their social role associated with the profession.

Voluntary reporting is authorized in very few jurisdictions. In the United States, there are only six States (North Carolina, Georgia, Maine, Maryland, New York, and Oregon) where the obligation of veterinarians is defined as a moral obligation or an obligation of conscience to report suspicious cases of mistreatment, ${ }^{21}$ which strictly speaking is not a legal obligation. In Canadian jurisdictions, only veterinarians in Ontario have the ethical duty to report suspicious injuries to animals. ${ }^{22}$ Regarding Europe, in Great Britain the heavy burden of this decision falls on the shoulders of the members of the Royal College of Veterinary Surgeons. ${ }^{23}$

Mandatory reporting. The protection of professional secrecy, like the protection of privacy, was never intended to be a shield for covering up criminal offences. Its main purpose is to protect clients against indiscretions by the professionals with whom they come into contact. The professional is only released from confidentiality in cases of extreme gravity in which the physical or psychic safety of a person may be in danger. ${ }^{24}$ Due to the vulnerability of the animal, as well as the link between human violence and violence against animals, veterinarians may at times be bound by the duty to report, much as in the duty to report in cases of youth protection. This duty is a real legal obligation under which the practitioner must report to the proper authorities any suspicious animal mistreatment or abuse.

Presented in this context, mandatory reporting may appear to resolve the ethical dilemma of the practitioner. But however effective it may sound, the actual enforcement of mandatory reporting is not always successful. Ethics and codes of

\footnotetext{
http://www.animallaw.info/articles/ddusvetreporttable.html.

Ontario Regulation, R.R.0. 1990, 1093.

3 The Veterinarian's Role in Domestic Violence, International Animal-Law: http://www.animallaw.biz/node/27.

24 See the Code of Professions, RSQ, vs C-26, a. 60.4; the Code of Ethics of Veterinary Surgeons, RLRQ, vs M-8, art. 25.1.
} 
professional practise are often confused (Lacroix and Létourneau, 2000). ${ }^{25}$ As a result, professionals often believe they have only a duty of conscience regarding such offences (Ouellette, 1977). ${ }^{26}$ This prevailing belief is reinforced by the fact that the failure to report abuse does not expose professionals to any disciplinary consequences: any resulting professional penalties, being neither physical nor monetary, do not seem to carry the same weight as legal penalties. They merely involve how the profession is practised:

The major limit to such a behavioral approach is linked to its disciplinary focus. A code of professional practise contains many more prescriptions than those which are effectively sanctioned. Professionals ... tend to focus only on factors that might lead to prosecution. All their attention focuses on what they need to do to protect themselves from such an eventuality. The attention is to "applying" the code, but the main purpose is to avoid any penalty. (Lacroix and Létourneau, 2000, p. 24) (Our translation)

Although it is legally binding for veterinarians in eight States (Arizona, California, Colorado, Illinois, Kansas, Minnesota, Oklahoma and West Virginia), the actual exercise of the duty to report occurs almost as infrequently in the United States as the actual exercise of the right to report under voluntary disclosure. In Canada, the legal duty to report has only been adopted by the professional orders of veterinarians in the jurisdictions of Newfoundland/Labrador ${ }^{27}$ and Quebevs. ${ }^{28}$

Because these jurisdictions have not set out any criminal penalties for professionals who fail to comply with this obligation, it seems very unlikely that cases of suspected abuse would be reported. Despite the duty to report, the deontological prescriptions to do so will continue to be seen by veterinarians as purely ethical issues.

It is also important to realize, however, that given how professionals perceive the justice system, they are rarely likely to choose to intervene. In North America, as well as in most industrial societies, there seems to be a crisis in juridical authority, which leads to a lack of trust in the criminal justice system (Crawford, 2008).

\section{Conclusion}

In this short text, we have attempted to demonstrate the active role that the veterinarian must play in conjunction with other stakeholders in civil society for the protection of animals. To quote veterinarian Debbie Stoewen (2011, p. 25):

25 "The main purpose of a code of ethics is to establish a standard of ethical behaviour to the extent that such codes may outline the duties and obligations of professional practise" (p. 30) (Our translation).

26 In disciplinary law, misconduct is effectively perceived as being the basis of "a violation of the moral and ethical principles specific to a given profession and arising from practise and tradition" (p. 670) (my translation).

27 Animal Health and Protection Act, S.N.L. 2010, vs A-9.1I.

28 Code of Ethics of Veterinary Surgeons, RLRQ, vs M-8, art. 56. 
While society is changing, it is also transforming the role played by veterinary medicine. Social reality is reflective of the major changes that have occurred in society: its challenges, opportunities and responsibilities. We [as veterinarians] all have the moral and collective responsibility to oversee the well-being of animals (my translation).

Many veterinarians hesitate to report animal mistreatment because they fear economic, physical and legal reprisal. Although not entirely recalcitrant in this respect, they are reluctant to betray professional secrecy despite their ethical duty to report.

Professional associations of veterinarians have a very important role to play in connection with their members. The Canadian Veterinary Medical Association (CVMA) has launched a website to help practitioners gain a better understanding of animal cruelty, the legal rules of disclosure, and the most appropriate response in such cases. ${ }^{29}$ The American Veterinary Medical Association (AVMA) and the American Animal Hospital Association (AAHA) have adopted a new policy dealing with reporting and disclosure. ${ }^{30}$

In conclusion, I wish to restate that my deepest hope is that the notion of "silence" will be freed from its original meaning, namely, the state of one who abstains from speaking. For at least one rare time in the life of animals, may silence resound only after all the complaints of so many abused animals fall silent - not because they are voiceless, but because they have at long last been relieved of their suffering.

Acknowledgement. The author is grateful to the Ordre des médecins vétérinaires du Québec for the support and cooperation it provided during research on the subject.

Call for Commentary: Animal Sentience publishes Open Peer Commentary on all accepted target articles. Target articles are peer-reviewed. Commentaries are editorially reviewed. There are submitted commentaries as well as invited commentaries. Commentaries appear as soon as they have been revised and accepted. Target article authors may respond to their commentaries individually or in a joint response to multiple commentaries.

Instructions: http://animalstudiesrepository.org/animsent/guidelines.html

29 http://veterinairesaucanada.net/ANIMAL-ABUSE.ASPX.

30 http://www.animallaw.info/articles/ddusvetreporttable.htm. 


\section{References}

Archambault vs Comité de discipline du Barreau du Québec, 1992 CanLII 3997 (QCCA).

Armstrong, S. J. (2003). The animal ethics reader. New York, NY: Psychology Press.

Association française d'information et de recherche sur l'enfance maltraitée (AFIREM) (1994). Secret maintenu, secret dévoilé : à propos de la maltraitance. Paris: Karthala.

Baudouin, J.-L. (1974), Le secret professionnel en droit québécois et canadien. R.G.D., $5,7-23$.

Bissonnette vs Mercure, T.P. Montréal, 500-07-000026-959, 96-06-20.

Briand vs Forget, 2007 QCCQ 10155 (CanLII).

Broom, D. M. (2014). Sentience and Animal Welfare. Wallingford: CABI.

Camos, V., Cézilly F., Guenancia P. \& Sylvestre J.-P. (Eds.) (2009). Homme et animal, la question des frontières. Paris: Quae.

Chapouthier, G. \& Bovet D. (2013). Les degrés de sensibilité dans le monde animal et leur identification scientifique in T. Auffret Van der Kemp \& M. Lachance (Eds.), La souffrance animale: de la science au droit. Cowansville: Yvon Blais.

Coulon, J.-M. (2013). De la science à la loi, quelle diversité d'approches juridiques à la sensibilité douloureuse des animaux? In T. Auffret Van der Kemp \& M. Lachance (Eds.), La souffrance animale: de la science au droit. Cowansville: Yvon Blais.

Crawford, A. (2008). Redéfinir le rôle de la communauté et des professionnels dans la police et la justice pénale in Justice, communauté et société civile, Shapland J. (Ed.). Paris: L'Harmattan.

D'Silva, J., \& Turner, J. (Eds.). (2012). Animals, ethics and trade: the challenge of animal sentience. Florence, KY: Routledge.

Dawkins, M. S. (2012). Why animals matter: animal consciousness, animal welfare, and human well-being. New York, NY: Oxford University Press.

Desmarais vs Autorité des marchés financiers, 2012 QCCS 6391 (CanLII). 
DeViney, E., Dickert J. \& Lockwood R. (1998). The care of pets within child abusing families in R. Lockwood \& F.R. Ascione, (Eds.), Cruelty to animals and interpersonal violence. West Lafayette, IN: Purdue University Press.

Duncan, I. J. (2006). The changing concept of animal sentience. Applied Animal Behaviour Science, 100(1), 11-19.

Felthous, A. R., \& Kellert, S. R. (1987). Childhood cruelty to animals and later aggression against people: a review. Arlington, VA: American Journal of Psychiatry.

Francione, G. (1994). Animals, Property and Legal Welfarism: "Unnecessary" Suffering and the "Humane" Treatment of Animals. Rutgers L. Rev., 46, 721-770.

Frazier, M. R. (1998). Physically and Sexually Violent Juvenile Offenders: A Comparative Study of Victimization History Variables 99. Logan, UT: Utah State University.

Frenette vs Métropolitaine (La), Cie d'assurance-vie, 1992 CanLII 35 (CSC).

Gagnon, A.-VS (2011). L'animal battu : une sentinelle muette de la violence domestique. La Dépêche vétérinaire, 1112, 19 au 25 février 2011.

Garrett, J. R. (Ed.) (2012). The ethics of animal research: exploring the controversy. Cambridge, MA: MIT Press.

Griffin, D. R. (2013). Animal minds: Beyond cognition to consciousness. Chicago, IL: University of Chicago Press.

Gullone, E. (2014). Risk factors for the development of animal cruelty. Journal of Animal Ethics, 4(2), 61-79.

Kant, E. (1967). Réflexions sur l'éducation. Paris: Vrin.

Labrie vs Roy, 2003 CanLII 8638 (QC CS).

Lacroix, A. \& Létourneau A. (Eds.) (2000). Méthode et intervention en éthique appliquée. Montréal: Fides.

Linzey, A. (Ed), Le Lien - Violence sur les animaux et sur les humains publié dans Les Cahiers antispécistes, CA no 35 (Novembre 2012). http://www.cahiersantispecistes.org/spip.php?article420 
Lockwood, R., \& Ascione, F. R. (Eds.) (1998). Cruelty to animals and interpersonal violence: Readings in research and application. West Lafayette, IN: Purdue University Press.

Maillard, N. (2011). La vulnérabilité : une nouvelle catégorie morale? Genève: Labor \& Fides.

Massol, H. (1862). De l'obligation naturelle et de l'obligation morale, en droit romain et en droit français (2nd ed.). Paris: Durand.

McIntosh, S. (Ed). (2004). The link between animal abuse and family violence as reported by women entering shelters in Calgary communities. Canadian Veterinary Medical Association http://canadianveterinarians.net/animal-abuse$\underline{\text { link.aspx }}$

Mead, M. (1964). “Cultural factors in the cause and prevention of pathological homicide.", Bulletin in the Menniger Clinic, No 28. (1964)

Monnier, S. (2006). Les comités d'éthique et le droit. Paris: L’Harmattan.

Morissette, Y.-M. \& SHUMAN D. W. (1984). Le secret professionnel au Québec : une hydre à trente-neuf têtes rôde dans le droit de la preuve. VS de D., 25, 501-532.

Ost, F. \& Gérard P. (1990). Droit et intérêt : entre droit et non-droit : l'intérêt; essai sur les fonctions qu'exerce la notion d'intérêt en droit privé. Bruxelles: Publications des Facultés Universitaires St-Louis.

Ouellette, Y. (1977). L'imprécision des codes de déontologie professionnelle. $R$. $d u$ B., $37,669-671$.

Pavia, M.-L. (1994). Éléments de réflexions sur la notion de droit fondamental. LPA, 54, 6 mai 1994.

Picard, É. (1998). L'émergence des droits fondamentaux en France. Les droits fondamentaux. Une nouvelle catégorie juridique?, AJDA, numéro spécial.

Poulin vs Prat, EYB 1994-64315 (VSA.).

Proctor, H. S., Carder, G., \& Cornish, A. R. (2013). Searching for animal sentience: a systematic review of the scientific literature. Animals, 3(3), 882-906.

Regan, T. (2003). Animal rights, human wrongs: an introduction to moral philosophy. Lanham, MD: Rowman \& Littlefield.

Ressler, R. K., Burgess A. W. \& Douglas J. E. (1988). Sexual homicide: Patterns and motives. Lexington, MA: Lexington Books. 
Rollin, B. E. (2015). The Inseparability of Science and Ethics in Animal Welfare. Journal of Agricultural and Environmental Ethics, 1-7.

Rollin, B. E., Prof. Bernard E. Rollin on Mandatory Reporting of Animal Cruelty: International Animal-Law. http://www.animal-law.biz/node/27

Safina, C. (2015). Beyond Words: What Animals Think and Feel. New York, NY: Macmillan.

Société d'énergie Foster Wheeler ltée vs Société intermunicipale de gestion et d'élimination des déchets (SIGED) invs, [2004] 1 RCS 456.

Stoewen, D. (2011). Le rôle des médecins vétérinaires et du programme SafePet dans les cas de violence. Le Vétérinarius, 27(1), Février.

Tiplady, V. S. (2013). Animal abuse: Helping animals and people. Wallingford: CABI.

Wakefield, L. (2013) What Is the Vet's Role in Animal Welfare? http://www.animalmosaivsorg/sentience/Debates/pastdebates $/$ default.aspx?page $=0 \&$ debate $=$ tcm:46-35604

Wise, S. (2014). Rattling the cage: Toward legal rights for animals. Jackson, TN: Da Capo Press.

The Israel Journal of Ecology and Evolution is seeking manuscript submissions for a special edition on Compassionate Conservation. Guest editors are Drs. Dror Ben-Ami and Daniel Ramp. They are inviting original research that is exemplary of Compassionate Conservation values. Compassionate Conservation builds the welfare of individual wildlife into conservation practice to improve outcomes for individuals, species and ecosystems. It has four guiding principles: a commitment to doing no harm as a starting point for intervention, individuals matter, all wildlife are worthy of conservation, and peaceful coexistence should be the ultimate aim for conservation practice. Practical examples include non-lethal management of wildlife populations, including animal welfare in conservation solutions, non-invasive monitoring techniques for studying wildlife, and engagement of human communities to minimise human-wildlife conflict.

For more information please contact Daniel Ramp at Daniel.Ramp@uts.edu.au 